\title{
POSSIBILITIES FOR DEVELOPMENT OF COMMODITY EXCHANGE IN SERBIA
}

\author{
Irena Janković ${ }^{1}$, Marko Jeločnik ${ }^{2}$, Jovan Zubović ${ }^{3}$ \\ *Corresponding authorE-mail: irenaj@ekof.bg.ac.rs
}

\begin{abstract}
A R T I C LE IN F O
A B S T R A C T

Review Article

Received: 25 September 2018

Accepted: 19 November 2018

doi:10.5937/ekoPolj1804557J

UDC 339.13.017(497.11)

Keywords:

commodity exchange, spot trading, forwards, futures, hedging strategies

JEL:Q02, Q11, 013

The aim of the paper is the analysis of the current situation related to the spot and non-standardised term commodity exchange market, as well as to provide a proposal for further improvement of commodity-trading in Serbia. The system of commodity-exchange trading in Serbia has not been developed and legislation has not been fully enacted. According to the analysis of price variability on three commodity markets it can be concluded that the fluctuations of prices of agricultural products in the last decade were very high, which led to market participants' need for term commodity exchange instruments. The paper presents suggestions for further improvement of the spot market as well as the clearing model on the forward market. The adoption of the Law on Commodity Exchange and amendments to the Law on Capital Market would improve the spot trading, trading of non-standardised and standardised term contracts.
\end{abstract}

(C) 2018 EA. All rights reserved.

\section{Introduction}

The commodity exchange is an institution that organises trading of goods and securities derived from commodities. On commodity exchanges both type of transactions can be organised, daily spot and term trading (Weber, 2000).

Spot trading is characterised by buying and selling commodities with delivery immediately after the conclusion of trading transaction. Spot trading in agricultural products is of low volume and rarely present on developed commodity markets. Term trading is related to delivery of goods in the future period. There are two types of term contracts - non-standardised and standardised (Working, 1953; Jayne et al., 2014).

1 Irena Janković, PhD, Assistant Professor, University of Belgrade, Faculty of Economics, Serbia, phone: +381 113021 046, E-mail: irenaj@ekof.bg.ac.rs

2 Marko Jeločnik, PhD, Research Associate, Institute of Agricultural Economics, Serbia, phone: +381 116972 858, E-mail: marko_j@iep.bg.ac.rs

3 Jovan Zubović, PhD, Senior Research Associate, Institute of Economic Sciences, Serbia, phone: +381 112622 357, E-mail: jovan.zubovic@ien.bg.ac.rs

http://ea.bg.ac.rs 
Spot (daily or prompt) markets of commodity exchanges allow traders to purchase and sale goods safely and transparently within delivery in a few days. Spot commodity trading, in addition, is improving trading security and inventory management of agricultural products $^{4}$, provides a very important function of price discovery, i.e. all participants in the market of agricultural products are allowed to see the realised trading price (Vavra, 2009).

Non-standardised term contracts, forwards, on agricultural products are traded on the Novi Sad Commodity Exchange, while this type of trading on worldwide commodity exchanges has relatively small volume.

Forward contracts are individual, not standardised in terms of quantity and delivery terms, which as a result has, as a rule, limited secondary trading (Kleinman, 2001; Kolb, Overdahl, 2007). Forwards, often called "green contracts" in domestic practice, are usually traded Over-the-counter (OTC) (Kovačević, Milošević, 2017). Futures and options are characterised by high standardisation in terms of timing of delivery, quantity of goods, place of delivery, etc. (Stošić Mihajlović, Zdravković, 2016).

Given the fact that forward contracts transactions are terminating in the future, there is a real possibility that by the timing of delivery of agricultural product the prices will change and one of the traders will suffer a loss. The possibility of a loss on a forward contract creates a risk of withdrawal from the execution of the contract of the losing party. In order to prevent withdrawal of contracting party from the forward contract, as well as the realisation of the counterparty risk, for reliable trading in forwards there is a need for a clearing house. It allows the depositing of guaranty deposits, so called margins, for each of the participants. The trader is obliged to deposit in the margin account in the case of unfavourable price movements and fall of the account coverage below a certain level (Kovačević, 2013; Jeločnik, 2017).

Forwards generally carry a high level of counterparty risk that shades contracts' execution in the future. In a situation in which the price of an underlying agricultural product is changed, a trading party that is generating loss i.e. can more favourable sell/buy the product in the spot market, has a motive not to execute the contract. The forward's feature is to be used for actual physical delivery of goods. They are not standardised that is an advantage as they are tailor-made to the traders' needs. On the other hand, this is also a disadvantage because secondary trading is limited (Geyser, 2000).

The most often short positions in forwards are held by agricultural producers and other actors in trade who are in possession or expect to be in possession of an agricultural product until the maturity of the contract (Harwood et al., 1999). In the situation when the buyer generates profit, the seller records the loss in the same amount and vice versa. The seller's profit is equal to the loss of the buyer. Based on this, it can be concluded that the sum of all gains on the forward market for agricultural products is equal to the sum of all losses (zero sum game).

4 Products on the commodity exchange are constantly available, thus, it is not necessary to keep high inventories. 
Forwards on agricultural products serve as instruments for managing the price risk (hedging strategies). Spot commodity trading is in decline on modern commodity exchanges, while the Commodity Exchange Novi Sad is one of the few commodity exchanges in the world that has retained a significant trading volume. According to the representatives of the Commodity Exchange Novi Sad trading volume is maintained due to a constant reduction in the exchange commission. The reasons that cause the disappearance of the spot commodity-exchange trading in agricultural products are listed in the next table (Table 1).

Table 1. Factors affecting the volume of spot commodity-exchange trading

\begin{tabular}{|l|l|}
\hline $\begin{array}{l}\text { Factors that positively affect the development } \\
\text { of spot commodity-exchange trading of } \\
\text { agricultural products }\end{array}$ & $\begin{array}{l}\text { Factors that negatively affect the development } \\
\text { of spot commodity-exchange trading of } \\
\text { agricultural products }\end{array}$ \\
\hline Limited transport system (based on railway) & Development of flexible truck transport \\
\hline $\begin{array}{l}\text { Poor ability of communication between buyers and } \\
\text { sellers, which makes it necessary for the two sides to } \\
\text { meet in a centralised market }\end{array}$ & $\begin{array}{l}\text { Development of IT facilitates the direct contact } \\
\text { between buyers and sellers avoiding the need for } \\
\text { direct meeting in a centralised market }\end{array}$ \\
\hline $\begin{array}{l}\text { A poor system of product standardisation, which } \\
\text { determines the need for immediate control of goods } \\
\text { by the buyer, on-site }\end{array}$ & $\begin{array}{l}\text { Development of quality standards and quality control } \\
\text { systems, which enables trade of goods according to } \\
\text { product description }\end{array}$ \\
\hline $\begin{array}{l}\text { Small scale production by a large number of non- } \\
\text { specialised producers (increasing the cost of direct } \\
\text { purchase) }\end{array}$ & $\begin{array}{l}\text { Production consolidation and the possibility of direct } \\
\text { purchase of large quantities of goods directly from } \\
\text { the producer }\end{array}$ \\
\hline $\begin{array}{l}\text { Domination of small traders that procure smaller } \\
\text { quantities of goods on central market }\end{array}$ & $\begin{array}{l}\text { Emergence of large traders who can directly order } \\
\text { large quantities of goods }\end{array}$ \\
\hline
\end{tabular}

Source: Authors' presentation based on Kohls, Uhl, 2002.

According to the previous table, the spot commodity-exchange trading (centralised market) loses its significance primarily due to the development of transport and telecommunication media that allow traders to contract fast delivery without the cost of a commodity exchange. It is important to note that the spot commodity market is more sensitive to the costs of exchange trading than the stock market for two reasons: firstly, supply and demand for agricultural products are more easily meeting outside the exchange than, for example, trading in shares and bonds, and secondly, after matching the orders the commodity must be transported to the standardised place for delivery of the commodity exchange, which increases the costs ${ }^{5}$, unlike, e.g. dematerialised shares that are only electronically transferred to the new owner.

Spot commodity-exchange trading is losing its significance, while term commodityexchange trading gains in significance. Thus, from year to year world commodity exchanges record an increasing volume of trading on the term market.

5 In order for goods to be traded on commodity exchange, supply does not contain information where goods are located, but the rules of the exchange define the place of delivery, most often river or sea harbor. In practice, this transportation does not occur. Direct delivery is made following the shortest route to the buyer, while from the seller the amount of transport costs to the standardised exchange point of delivery is deducted, which represents a significant expense. 
Regarding the legislation, there is a significant difference between spot and non-standardised trading on one hand and standardised term trading on the other. There is a difference between the legislation regulating the spot and forward commodity market and trading of derivative securities (options, futures and swaps). Within the EU, spot trading legislation is not subject of common EU regulations, thus each EU Member State regulates this area individually. In the case of derivative securities, common EU regulations have been established, where all EU member states must be harmonised. On the other hand, path for the development of commodity-exchange operations in Serbia is to improve the existing spot trading and establish term trading (Veselinović et al., 2014, Kovačević, Vasiljević, 2017, Kuzman et al., 2018).

Commodity Exchange Novi Sad is the only commodity exchange in Serbia that for several decades organised the spot trading, while the term trading with forward contracts has relatively small presence and faces a high degree of risk.

In previous decades, extreme price volatility of agricultural products on commodity markets worldwide have been an important topic for analysis, as it is usually connected to insecurity and financial risks for all actors within the supply chain (FMFA, 2015).

Price fluctuations are primarily the result of the mutual confrontation between the parameters of food availability (e.g. weather conditions, planned production volume, policies turned to public incentives, previous supplies, foreign trade trends, length of market chain, state of elements of market infrastructure, legislation, etc.) and the macroeconomic factors to the current demand (e.g. rates of population and GDP growth, purchasing power, general level of employment, presence of inflation, quality of available food and income distribution, etc.), (Erokhin, 2017). Significant price fluctuation of agricultural products caused the need for establishment of economic instruments that will enable managing the price risks. It was provided by development of commodity and financial derivatives during the 1970s (Zakić, Vasiljević, 2013).

\section{Materials and methods}

Given that the fluctuation of agricultural products prices represents one of the key drivers of the development of modern commodity markets, the price of corn is analysed in order to reach a conclusion on the need to establish more developed commodityexchange operations for participants that trade in cereals.

In order to demonstrate the increasing need for improvement of spot trading and development of term trading on commodity exchange in Serbia, in this paper, in addition to in-depth interview with relevant experts within the field of commodity exchanges and risk management models in agriculture, authors referred to the data set on corn trading on three relevant international commodity exchanges: CME (Chicago Mercantile Exchange, USA), MATIF (Marché à Terme International de France, Paris) and Commodity exchange Novi Sad (Serbia). Data series variability was calculated in order to determine the need of hedging strategies for Serbian farmers. Linear regression is applied in order to identify the trend at Commodity Exchange Novi Sad trading volume behaviour. 
The rational for using corn prices is the fact that corn is the one of the most relevant commodity exchanges trading material. Furthermore, corn prices are taken from CME because it is the largest commodity exchange in the world and those data are considered as a "global corn price". On the other hand, MATIF data are used due to the fact that this is the largest commodity exchange in Europe with significant effect on Serbian grain prices. Commodity exchange Novi Sad is only commodity exchange in Serbia and its price information are most relevant for local market.

\section{Results and Discussion}

Data encompass daily closing prices for corn in USD/t. Available time span differs for each series: 3 Jan 2007-25 May 2018 for Commodity Exchange Novi Sad data, 13 Jan 2010-25 May 2018 for CME data and 12 May 2011-25 May 2018 for MATIF data on corn prices.

Figure 1. Corn prices on the Commodity Exchange Novi Sad, CME and MATIF, in the period 2007-2017, in USD/t

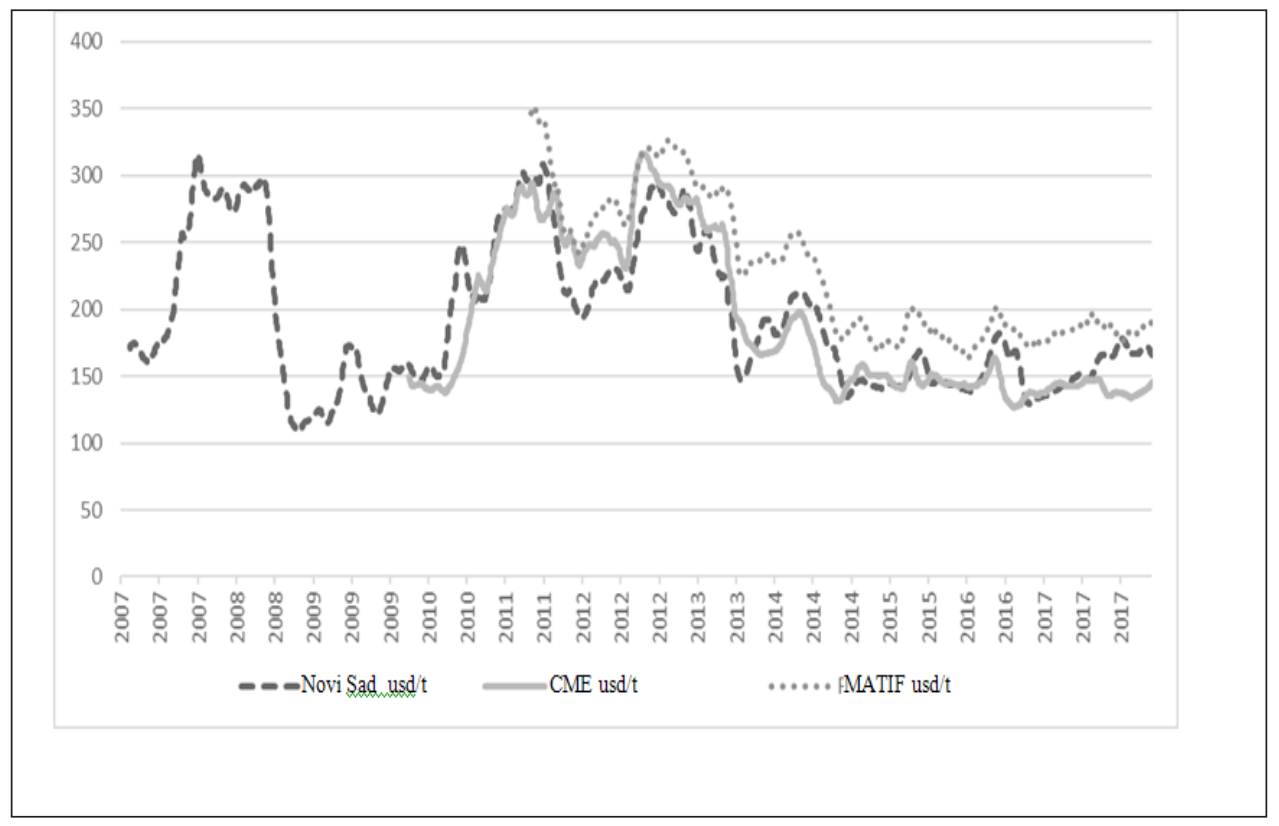

Source: Commodity Exchange Novi Sad, 2018a; CME, 2018; MATIF, 2018

In previous chart are presented the corn prices recorded on the Commodity Exchange in Novi Sad, CME and MATIF. What could be noticed is the significant variability of the corn prices on all three markets, that determines the need for the development of the term commodity trading on Serbian market, too (it already exists on CME and MATIF). That would enable traders of agricultural products to apply hedging strategies in order to protect their income from price risks. 
The need for a term market in order to manage the risk of adverse movements in prices of agricultural products in the future is directly proportional to the fluctuation of the prices of agricultural products. With higher price fluctuations farmers will have a greater need to sell their products while they are still on the field, for the delivery in the harvest period (Madre, Devuyst, 2016).

In order to determine and confirm the needs of farmers in Serbia for the developed term market for agricultural products, an analysis of the fluctuation of corn prices in the period 2007-2018 was carried out.

Table 2. Measures of the corn price variability in Serbia, in period 2007-2018

\begin{tabular}{|l|r|}
\hline \multicolumn{1}{|c|}{ Serbia } & \multicolumn{1}{|c|}{ Corn price } \\
\hline Standard deviation & 55.31 \\
\hline Variance & $3,059.14$ \\
\hline Average & 192.77 \\
\hline Coefficient of variation & 0.29 \\
\hline
\end{tabular}

Source: Authors' calculation

The fluctuation of corn prices in the observed period is highly significant and there is almost no other sector of the economy in which this level of price fluctuation exists.

Figure 2 presents the trading volume on the daily spot market at the Commodity Exchange in Novi Sad (trade with corn, soya, wheat, etc.). It could be noticed that the trading volume has a mildly declining but almost stagnant trend.

Figure 2. Volume of trading on the Commodity Exchange in Novi Sad (in thousands of tons), in the period 2001-2018

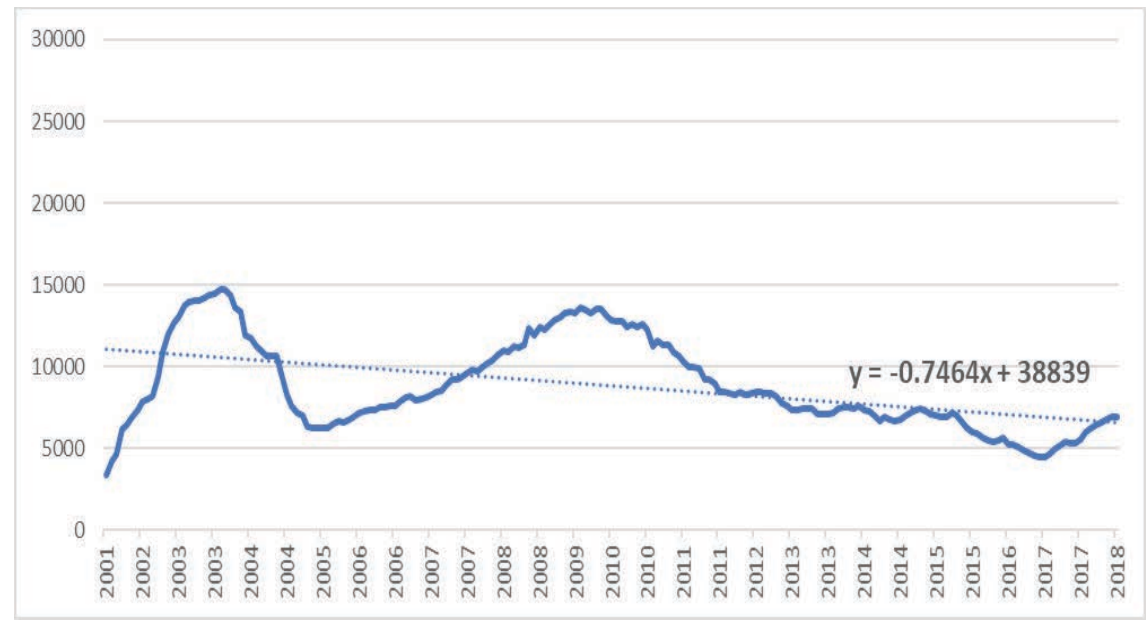

Source: Commodity Exchange Novi Sad, 2018 b. 
The Commodity Exchange Novi Sad in Serbia is one of the rare exchanges trading forwards. In next table (Table 3) is presented the total volume of forward trading at the Novi Sad Commodity Exchange. Since in literature there is no clear division between the spot and forward contracts in respect of delivery time, for the purposes of this paper analysis, in forwards contracts are classified all the contracts with a delivery longer than thirty days.

Table 3. Number of forward contract traded on Commodity Exchange Novi Sad, in the period January 2015 - June 2018

\begin{tabular}{|l|r|}
\hline \multicolumn{1}{|c|}{ Year } & \multicolumn{1}{|c|}{ Number of contracts } \\
\hline Jan -June 2018 & 52 \\
\hline 2017 & 60 \\
\hline 2016 & 21 \\
\hline 2015 & 5 \\
\hline
\end{tabular}

Source: Commodity Exchange Novi Sad, 2018b.

According to the data from previous table, it could be seen that although relatively negligible trade is recorded, there is significant increase in number of contracts traded within the observed period.

Figure 3. Total volume of trading in tons on forward contracts on the Commodity Exchange Novi Sad, in the period January 2015 - June 2018

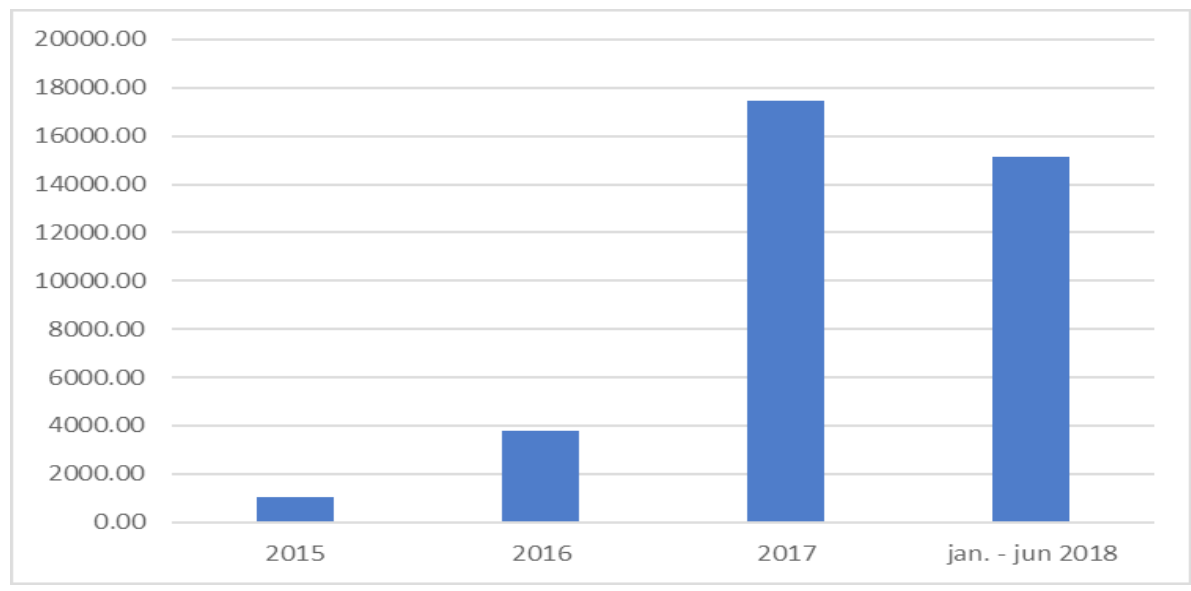

Source: Commodity Exchange Novi Sad, 2018b

For the analysed period, both the number and the quantity of agricultural products in forward contracts have been significantly increased, indicating that farmers have a pronounced need for a timely and secured sale of agricultural products. 
Figure 4. Mechanism of term trading of agricultural products on the Novi Sad Commodity Exchange

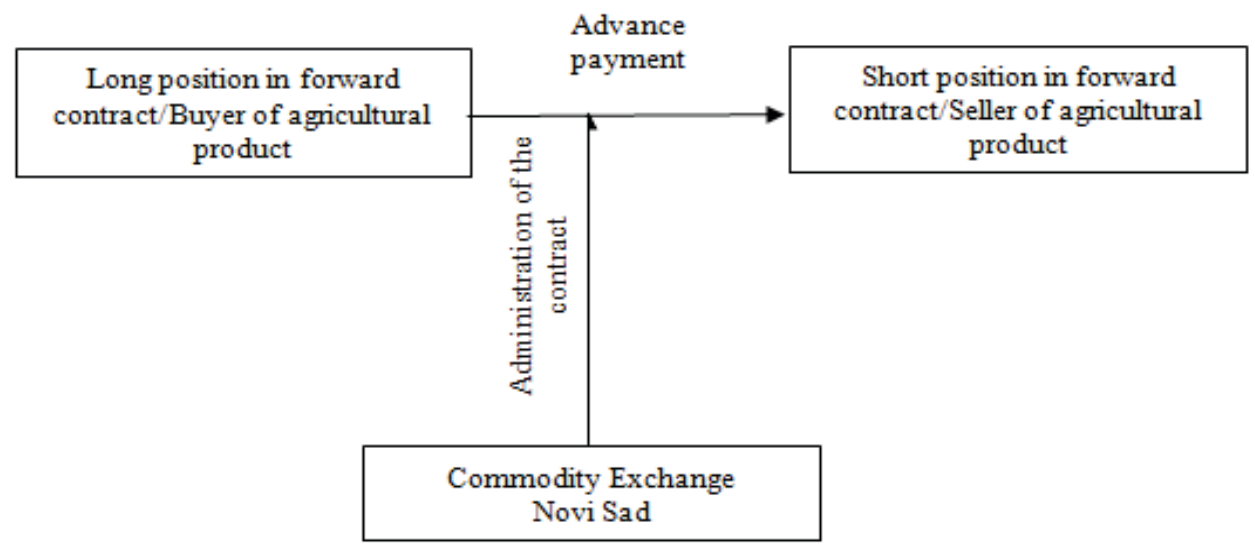

Source: Authors' presentation

According to the above scheme, after the conclusion of the forward contract, the buyer pays the full amount to the seller. The Commodity Exchange Novi Sad administrates all operations related to the conclusion of the transaction, such as: order announcement, matching of orders, contract notes for the orders executed, informing traders, etc. There is no guarantee of fulfilment of the contractual obligation of the seller. Thus, after the complete purchase price is paid there still remains the risk of avoiding the delivery of goods by the seller. The counterparty risk is the basic lack of this type of trading, as well as primary obstacle for the development of the non-standardised term market in Serbia.

In line to the findings in this paper, on the spot market, commodity trading inherent to developed commodity exchanges, in Serbia has not been established.

Comparative analyses in Table 4 presents the current trading model on Commodity Exchange in Serbia, as well as characteristics of the models of developed commodity markets.

Table 4. Comparative analysis of the current trading model on the Commodity Exchange in Novi Sad and trading model characteristics of the developed commodity exchanges

\begin{tabular}{|l|l|l|}
\hline \multicolumn{1}{|c|}{ Elements } & \multicolumn{1}{|c|}{$\begin{array}{c}\text { Developed commodity } \\
\text { exchanges }\end{array}$} & $\begin{array}{c}\text { Commodity Exchange Novi } \\
\text { Sad }\end{array}$ \\
\hline $\begin{array}{l}\text { Licensing and controlling the } \\
\text { commodity market }\end{array}$ & Obligatory & Not established \\
\hline $\begin{array}{l}\text { Mandatory capital censorship for the } \\
\text { operation of the commodity market }\end{array}$ & Established & Not established \\
\hline Clearing and settlement system & Established & Not established \\
\hline $\begin{array}{l}\text { Licensing and controlling of the } \\
\text { commodity market members }\end{array}$ & Established & Not established \\
\hline Spot trading & Infrequently & Established \\
\hline $\begin{array}{l}\text { Trading of non-standardised term } \\
\text { contracts (forwards) }\end{array}$ & Infrequently & $\begin{array}{l}\text { Established with increasing } \\
\text { trend }\end{array}$ \\
\hline
\end{tabular}




\begin{tabular}{|l|l|l|}
\hline \multicolumn{1}{|c|}{ Elements } & \multicolumn{1}{|c|}{$\begin{array}{c}\text { Developed commodity } \\
\text { exchanges }\end{array}$} & $\begin{array}{c}\text { Commodity Exchange Novi } \\
\text { Sad }\end{array}$ \\
\hline $\begin{array}{l}\text { Trading of standardised term contracts } \\
\text { (futures and options) }\end{array}$ & Established & Not established \\
\hline $\begin{array}{l}\text { Out-of-court dispute settlement system } \\
\text { (commodity exchange arbitrage) }\end{array}$ & Established & $\begin{array}{l}\text { Not established (traders in } \\
\text { situation of dispute have to } \\
\text { rely on court processes) }\end{array}$ \\
\hline $\begin{array}{l}\text { Guarantee deposit system that } \\
\text { guarantees execution of the contract }\end{array}$ & Established & Not established \\
\hline
\end{tabular}

Source: Authors' presentation

Based on the comparative analysis, it may be concluded that the legal framework for the operability of the commodity spot market, which would define the system of licensing and control of commodity exchanges and thus improve the security of trading, has not been established in Serbia.

The "level of services" that the commodity exchange provides to traders is of high importance (UNCTAD, 2009). The level of services on the local commodity exchange is low because, after matching of exchange orders, the buyer and the seller receive information on each other and they have to take care about the delivery of goods and the payment (the clearing and settlement functions on the commodity exchange are not established). Draft Law on Commodity Exchange proposes that settlement and clearing should operate on commodity exchange throughout the specialised accounts so that commodity exchange takes care of the delivery and payment of goods. In that system the buyer transfers funds to the specialised account on the exchange, and not directly to the seller, as is now the practice, while the exchange after the receipt of the certificate of delivery of goods transfers the funds to the seller. In addition to increased level of commodity-exchange services, through clearing and settlement, the level of security in trading could be also raised (MTTT, 2018).

Besides the types of trading instruments and services level, trading security is the third pillar that determines the success of commodity market. In Serbia, in case of an exchange dispute, participants in trading are referred to the dispute resolution in regular court proceedings (there is no out-of-court dispute settlement established on the commodity exchange).

Furthermore, with regard to the security of execution of the contract, there are no guarantees established through deposits that are a precondition for listing of a trading order. In the spot trading, these deposits serve as a counterparty compensation in the event of the cancellation of the execution of the contract. In trading of non-standardised term contracts, currently, there are no guarantees for execution of contracts (margin accounts).

According to the previously shown results of the analysis in Serbia, a developed commodity market has not been established, since important elements of commodity exchange operations are missing. 
In this part of the paper, the possibility of development of the spot and non-standardised commodity market will be analysed in more detail. Draft Law on Commodity Exchanges proposed by the Ministry of trade, tourism and telecommunications, which should regulate the mentioned area, is in the adoption procedure. This document defines only spot and forward trading, while the area of derivative securities is left to the authority of the Law on Capital Market. There is no legal framework for commodity exchanges in Serbia, despite the fact that the first draft law was initiated in 1992. So far, seven working groups have been formed in different ministries.

In line to the conducted analysis, the following areas for improvement of the legal framework related to spot and non-standardised term trading have been identified:

1. Introduction of the licensing system and control of the operations of commodity exchanges by the Security and Exchange Commission.

2. Introduction of clearing system on the commodity market, through a consolidated specialised account managed by the commodity exchange. Through the clearing function, additional services are offered to traders as well as a significant increase in security of trading. The practice has so far been that the buyer and the seller get information about each other and they themselves take care of the delivery while the payment is done in advance. This has caused a number of problems in practice, especially in cases when seller did not deliver the goods as agreed after the advance payment. In the new system, the buyer will pay the funds to a collective specialised account, while the commodity exchange will transfer the funds to the seller upon the reception of the evidence of goods delivery. In this way, without significantly raising the costs of trading, the service offered to traders by the commodity exchange will be greatly improved that may lead to significant reduction of risks.

3. Introduction of obligatory guarantee deposits in spot trading which are necessary to place the order in the quotation. In this way, trade security is increased and counterparty risk is reduced.

4. Introduction of the exchange arbitrage in situations of traders disputes.

5. In forward contracts trading, the introduction of required margin accounts for both parties, which are marked to market on a daily basis in the case of goods with a high volume of spot trading. The required amounts to be deposited are fixed on high level for goods traded with a small volume on spot market.

6. The possibility that margin on forward contracts may be deposited, in addition to money, in other forms of liquid assets such as: bank guarantee, government securities, etc., which significantly reduces the costs of trading.

Considering the fact that, a significant need to improve trading of non-standardised term contracts is noticed, a model for the development of non-standardised commodity trading is analysed in more detail in Table 5. 
Table 5. The analysis of forward contracts trading on commodity exchanges

\begin{tabular}{|l|l|}
\hline \multicolumn{1}{|c|}{ Advantages } & \multicolumn{1}{|c|}{ Disadvantages } \\
\hline $\begin{array}{l}\text { They are not standardised, allowing the buyer and seller to } \\
\text { trade with the quantity and within the delivery period that } \\
\text { suits both parties }\end{array}$ & $\begin{array}{l}\text { They are not liquid, i.e. secondary trading is } \\
\text { difficult, unlike the futures, and thus leaving } \\
\text { the contract is not possible }\end{array}$ \\
\hline $\begin{array}{l}\text { It provides physical delivery of goods and do not face the } \\
\text { basis risk as in the futures }\end{array}$ & High counterparty risk \\
\hline $\begin{array}{l}\text { Lower costs of guarantees for participants in trading in } \\
\text { comparison to the guaranties in futures (there is no transfer } \\
\text { of funds between the buyer and the seller, therefore, liquid } \\
\text { assets can be used in addition to money, for example, bank } \\
\text { guarantees, government securities, etc.) }\end{array}$ & $\begin{array}{l}\text { Determining the price at which the forward } \\
\text { is settled is complicated given the fact that } \\
\text { there is no reference market price, as in the } \\
\text { case of futures. }\end{array}$ \\
\hline $\begin{array}{l}\text { Forward trading does not require a high volume of trading as } \\
\text { opposed to futures for which market liquidity is a prerequisite } \\
\text { for maintaining trade. }\end{array}$ & \\
\hline
\end{tabular}

Source: Authors' presentation

A legal basis for the development of clearing on a non-standardised forward market is necessary, while the mechanism itself and the operation of clearing can be specified in the by-laws. Due to the importance of clearing for the successful forward trading on commodity exchanges, analysed and presented is a potential clearing mechanism (Table 6). The basic differences between clearing in a standardised and non-standardised markets are:

1. On a standardised market, the settlement price of a contract is known. Most often it is the last price of the contract at the end of the trading day, while in the forward market the price of the contract, based on which the guarantee deposits of traders will be settled (margin accounts), does not exist. Therefore, in the case of a forward, the settlement price of the contract must be calculated.

2. Standardised forward contracts are highly liquid and, in the case of a default of one counterparty, the clearing house simply closes the position of the defaulting party by selling the position. Forwards are individual and, therefore, less liquid than futures contracts, so in this case a position that is in a default cannot be sold and another solution must be sought to close this position.

Table 6. Proposal of the basic elements of clearing in the non-standardised term market

\begin{tabular}{|l|l|}
\hline \multicolumn{1}{|c|}{ Elements } & \multicolumn{1}{|c|}{ Clearing model activities } \\
\hline Calculation of the settlement price & $\begin{array}{l}\text { Adding storage costs in the period up to the moment of delivery of } \\
\text { goods on the daily spot price. }\end{array}$ \\
\hline Liquidation of the defaulting position & $\begin{array}{l}\text { Transferring a guarantee deposit from the party that is in a default to } \\
\text { the other party in the contract. }\end{array}$ \\
\hline The length of the contract maturity & $\begin{array}{l}\text { Contracts should be active until the harvest (they could not last } \\
\text { longer due to the difficulty in calculating the settlement price of a } \\
\text { contract). }\end{array}$ \\
\hline Guaranty deposits & $\begin{array}{l}\text { All liquid assets - traders could deposit money, bank guarantees and } \\
\text { government bonds. In the case of a seller, by placing a warehouse } \\
\text { receipt at the commodity exchange, the obligation to lay down other } \\
\text { guarantees would cease. }\end{array}$ \\
\hline
\end{tabular}


In the Central and Eastern European countries, the term commodity trading in agricultural products has not been established ${ }^{6}$. The trading in this type of financial instruments is also very low in the EU compared to the USA and some Asian countries (Belozertsev et al., 2011). By establishing an efficient commodity-exchange system, Serbia could become a regional centre for commodity-trading for participants from countries that do not have the preconditions for establishing a commodity market.

\section{Conclusions}

Commodity-exchange trading has not been established in Serbia. Significant fluctuation of agricultural product prices during the last few decades is deriving demand for the development of term commodity-exchange which would allow market participants to apply hedging strategies in order to ensure the commodity price in the upcoming period.

On the spot market organised by the Commodity Exchange Novi Sad, trading is not characterised by features that are specific for the developed exchanges. There is no clearing system, exchange arbitrage, procedures for licensing and control of exchange market operations, etc.

Within the non-standardised trading organised by the Commodity Exchange Novi $\mathrm{Sad}$, the buyer and the seller, after the conclusion of the exchange contract, have to take care about the delivery and payment of goods. There is no system of guarantees pledging that would guarantee that both parties will execute the contract in case of an unfavourable price movements.

The main reason for the underdeveloped commodity market in Serbia is the lack of harmonised legal regulations for spot commodity exchanges, as well as the nonharmonised Law on the Capital Market with common EU regulations in this field.

The Draft Law on Commodity Exchange is in the adoption procedure. The draft has defined a clear scope of jurisdiction for spot and non-standardised term trading.

It is necessary to introduce a simple mechanism of clearing based on the consolidated specialised accounts managed by the exchange. This system would allow the payment of funds to the seller after delivery of goods. By introducing this simple mechanism, traders receive a significantly higher level of security, as well as the level of services.

Legal regulation of the system of licensing and control of commodity exchange by the Securities and Exchange Commission would increase safety and uniformity in the operations of all commodity exchanges.

In the forward contracts trading, the obligation to place a guarantee amount on margin accounts should be introduced, which would create, for the first time in Serbia, a forward contract with the institutional guarantees of execution.

6 The trading of futures on the exchange in Budapest completely ceased. 
Based on the analysis, it may be concluded that the adoption of the Draft Law on Commodity Exchanges and amendments to the Law on Capital Market would enable the development of commodity-exchange operations in Serbia. Given the fact that a large number of countries in the region do not meet the prerogatives to develop commodity trading, Serbia could become a regional centre. By amending and harmonising the Law on Capital Market, a possibility would be created for inclusion of Serbia's commodity exchange in the common futures market of cereals in the region.

\section{Acknowledgements}

Paper is a part of research on the projects: 179005, III 46006 and 179015 financed by the Ministry of Education, Science and Technological Development of the Republic of Serbia.

The authors owe their special gratitude to the Director of the Commodity Exchange Novi Sad, Mr. Miloš Janjić, and the Director of Trading on the Commodity Exchange, Novi Sad, Mr. Radoslav Pilja on the assistance in preparation of this paper, provided data and expert comments.

\section{Conflict of interests}

The authors declare no conflict of interest.

\section{References}

1. Belozertsev, A., Rutten, L., \& Hollinger, F. (2011). Commodity exchange in Europe and Central Asia: A means of management of price risk, working paper no. 5, FAO Investment Centre, Food and Agriculture Organization of UN, Rome, Italy. Retrieved from www.eastagri.org/publications/pub_docs/ Europe\%20and\%20Central\%20Asia_web2.pdf

2. CME. (2018). Data on corn prices for the period 2010-2018. Web portal of CME Group (Chicago Mercantile Exchange), Chicago, USA, Retrieved from www.cmegroup.com

3. Commodity Exchange Novi Sad. (2018a). Data on corn prices for the period 2007-2018. Web portal of Commodity Exchange Novi Sad, Serbia. Retrieved from www.proberza.co.rs/

4. Commodity Exchange Novi Sad. (2018b). Total volume of trading and number of forward contract traded, Commodity Exchange in Novi Sad, Serbia, data obtained on request during the July 2018.

5. Erokhin, V. (2017). Factors influencing food markets in developing countries: An approach to assess sustainability of the food supply in Russia. Sustainability, 9(8/1313), 1-13. doi:10.3390/su9081313 
6. FMFA. (2015). Price fluctuations (volatility) of agricultural commodities, Federal Ministry of Food and Agriculture (FMFA), Berlin, Germany. Retrieved from www.bmel.de/EN/Agriculture/Market-Trade-Export/_Texte/ Preisvolatilitaet.html

7. Geyser, J. M. (2000). Decision support system to manage investment risk of grain farmers in South Africa, PhD thesis, University of Pretoria, Pretoria, SAR.

8. Harwood, J., Heifner, R., Coble, K., Perry, J., \& Somwaru, A. (1999). Managing Risk in Farming: Concepts, Research, and Analysis, Agricultural Economic Report, no. 774, Economic Research Service (RSA), U.S. Department of Agriculture (USDA), Washington, USA.

9. Jayne, T. S., Sturgess, C., Kopicki, R., \& Sitko, N. (2014). Agricultural Commodity Exchanges and the Development of Grain Markets and Trade in Africa: A Review of Recent Experience, working paper no. 88, Indaba Agricultural Policy Research Institute (IAPRI), Lusaka, Zambia, 1-30.

10. Jeločnik, M. (2017). Economic instruments for climate risks management in crop production in Republic of Serbia, Doctoral Dissertation, University of Novi Sad, Faculty of Agriculture, Novi Sad, Serbia (Ekonomski instrumenti za upravljanje klimatskim rizicima u ratarskoj proizvodnji Republike Srbije, doktorska teza, Poljoprivredni fakultet, Univerzitet u Novom Sadu, Novi Sad, Srbija).

11. Kleinman, G. (2001). Commodity futures and options: A step by step guide to successful trading. Prentice Hall, NJ, USA.

12. Kohls, R., \& Uhl, J. (2002). Marketing of agricultural products. Prentice Hall, NJ, USA.

13. Kolb, R., \& Overdahl, J. (2007). Futures, Options and Swaps, 5th edition. Blackwell Publishing, NJ, USA.

14. Kovačević, V. (2013). Introduction of the grain futures market in the Black Sea region. Economics of Agriculture, 60(4), 695-712. UDC: 339.13:633.11(262.5)

15. Kovačević, V., \& Milošević, I. (2017). Significance and Development Preconditions of Commodity Exchange Trade with Agricultural Products in Serbia (Značaj i preduslovi razvoja berzanskog trgovanja poljoprivrednim proizvodima u Srbiji). Škola biznisa, 10(2), 172-178. DOI 10.5937/ skolbiz2-14320

16. Kovačević, V., \& Vasiljević, Z. (2017). Development of commodity exchanges in function of agribusiness in Serbia, in: Sustainable agriculture and rural development in terms of the Republic of Serbia strategic goals realization within the Danube region: Development and application of clean technologies in agriculture, (Eds.) Vasile, J., Subic, J., Kuzman, B., Institute of Agricultural Economics, Belgrade, Serbia, 430-445. 
17. Kuzman, B., Ercegovac, D., \& Momčilović, M. (2018). Development of derivative trading on financial market and agribusiness sector in Serbia. Economics of Agriculture, 65(2), 601-616. doi:10.5937/ekoPolj1802601K

18. Law on Capital Market, Official Gazette of the Republic of Serbia, no. 31/2011.

19. Madre, Y., \& Devuyst, P. (2016). Are futures the future for farmers?, web portal of Farm Europe, Bruxelles, Belgium, Retrieved from www.farm-europe.eu/ travaux/are-futures-the-future-for-farmers-2/

20. MATIF. (2018). Data on corn prices for the period 2011-2018., web portal of MATIF (Marché à Terme International de France), Paris, France, Retrieved from www.euronext.com/en

21. MTTT. (2018). Draft Law on Commodity Exchange, Ministry of trade, tourism and telecommunications of the Republic of Serbia, Retrieved from http://mtt. gov.rs/slider/jr-nacrt-zakona-orr/?script=lat

22. Stošić Mihajlović, Lj., \& Zdravković, I. (2016). Forward, future and options on stock exchange market. Journal of Process Management - New Technologies, International, 4(3), 50-56. doi:10.5937/jouproman4-11324

23. UNCTAD. (2009). Development Impacts of Commodity Exchanges in Emerging Markets, report, United Nations Conference on Trade and Development (UNCTAD), Geneva, Switzerland.

24. Vavra, P. (2009). Role, Usage and Motivation for Contracting in Agriculture, OECD Food, Agriculture and Fisheries Working papers, no. 16, OECD Publishing, Paris, France, 1-36.

25. Veselinović, J., Marković, T., \& Đukić, S. (2014). Analysis of legal and economic aspects of precipitation weather derivatives for Serbian agricultural sector. Economics of Agriculture, 61(4), 1053-1067. UDC: 551.502.4:347.447(497.11)

26. Weber, M. (2000). Commerce on the Stock and Commodity Exchanges. Theory and Society, 29(3), 339-371. Retrieved from https://www.jstor.org/ stable/3108486

27. Working, H. (1953). Futures Trading and Hedging. The American Economic Review, 43(3), 314-343.

28. Zakić, V., \& Vasiljević, Z. (2013). Establishment of the commodity derivativesmarket in the function of agribusiness sector improvement in Serbia (Uspostavljanje tržišta robnih derivata u funkciji unapređenja agrosektora $\mathrm{u}$ Srbiji). Ekonomski vidici, 18(1), 49-61. 